\title{
Altered CELF1 binding to target transcripts in malignant $T$ cells
}

\author{
PAUL R. BOHJANEN, ${ }^{1,2,3}$ MAI LEE MOUA, ${ }^{1,3}$ LIANG GUO, ${ }^{1,3}$ AMMANUEL TAYE, ${ }^{1,3}$ \\ and IRINA A. VLASOVA-ST. LOUIS ${ }^{1,3}$ \\ ${ }^{1}$ Department of Medicine, University of Minnesota, Minneapolis, Minnesota 55455, USA \\ ${ }^{2}$ Department of Microbiology, University of Minnesota, Minneapolis, Minnesota 55455, USA \\ ${ }^{3}$ Center for Infectious Diseases and Microbiology Translational Research, University of Minnesota, Minneapolis, Minnesota 55455, USA
}

\begin{abstract}
The RNA-binding protein, CELF1, binds to a regulatory sequence known as the GU-rich element (GRE) and controls a network of mRNA transcripts that regulate cellular activation, proliferation, and apoptosis. We performed immunoprecipitation using an antiCELF1 antibody, followed by identification of copurified transcripts using microarrays. We found that CELF1 is bound to a distinct set of target transcripts in the $\mathrm{H} 9$ and Jurkat malignant T-cell lines, compared with primary human T cells. CELF1 was not phosphorylated in resting normal $\mathrm{T}$ cells, but in malignant $\mathrm{T}$ cells, phosphorylation of CELF1 correlated with its inability to bind to GRE-containing mRNAs that served as CELF1 targets in normal T cells. Lack of binding by CELF1 to these mRNAs in malignant T cells correlated with stabilization and increased expression of these transcripts. Several of these GRE-containing transcripts that encode regulators of cell growth were also stabilized and up-regulated in primary tumor cells from patients with T-cell acute lymphoblastic leukemia. Interestingly, transcripts encoding numerous suppressors of cell proliferation that served as targets of CELF1 in malignant $T$ cells, but not normal $T$ cells, exhibited accelerated degradation and reduced expression in malignant compared with normal $T$ cells, consistent with the known function of CELF1 to mediate degradation of bound transcripts. Overall, CELF1 dysfunction in malignant T cells led to the up-regulation of a subset of GRE-containing transcripts that promote cell growth and down-regulation of another subset that suppress cell growth, producing a net effect that would drive a malignant phenotype.
\end{abstract}

Keywords: GU-rich element; GRE; CELF1 phosphorylation; mRNA stability; cancer

\section{INTRODUCTION}

Precise regulation of mRNA turnover is critical for normal gene expression during cell growth, activation, and differentiation (Raghavan and Bohjanen 2004; Turner and Hodson 2012), and abnormal stabilization of growth-promoting transcripts can lead to malignant proliferation (for review, see Khabar 2010). Specific target sequences in mRNA can interact with RNA-binding proteins to coordinately regulate networks of transcripts involved in cell growth and development (Vlasova-St. Louis et al. 2013) or other biological processes (Keene 2007; Blackinton and Keene 2014). A well-characterized example is the AU-rich element, which interacts with RNA-binding proteins to coordinate gene expression over the course of immune responses (Raghavan et al. 2002; Ogilvie et al. 2005, 2009; Mukherjee et al. 2009; VlasovaSt. Louis and Bohjanen 2014). A more recently identified regulatory motif, known as the GU-rich element (GRE), is found in the $3^{\prime}$ untranslated regions (UTRs) of transcripts

Corresponding author: vlaso001@umn.edu

Article published online ahead of print. Article and publication date are at http://www.rnajournal.org/cgi/doi/10.1261/rna.049940.115. that encode regulators of cell growth, activation, differentiation, and apoptosis (Vlasova et al. 2008; Beisang and Bohjanen 2012). The GRE serves as the binding target of the protein, CUGBP and ELAV-like family member 1 (CELF1), which functions to mediate the rapid degradation of GREcontaining transcripts (Vlasova and Bohjanen 2008). During T-cell activation, GREs coordinate the degradation of transcripts involved in cell growth and apoptosis (Beisang et al. $2012 \mathrm{~b}$ ). The presence of GREs in the $3^{\prime} \mathrm{UTR}$ s of numerous transcripts have also been associated with rapid mRNA degradation during muscle cell differentiation (Lee et al. 2010) or Xenopus oocyte development (Wu et al. 2010). CELF1 has also been shown to coordinately regulate other post-transcriptional processes including alternative splicing and translation (for review, see Vlasova and Bohjanen 2008; Beisang et al. 2012a).

(C) 2015 Bohjanen et al. This article is distributed exclusively by the RNA Society for the first 12 months after the full-issue publication date (see http://rnajournal.cshlp.org/site/misc/terms.xhtml). After 12 months, it is available under a Creative Commons License (Attribution-NonCommercial 4.0 International), as described at http://creativecommons.org/licenses/by$\mathrm{nc} / 4.0 \%$. 
We have shown that CELF1 binds to a network of GREcontaining transcripts in primary human $\mathrm{T}$ cells (Beisang et al. 2012b). As early as $6 \mathrm{~h}$ following T-cell activation, the CELF1 protein becomes phosphorylated, which decreases its ability to bind to GRE-containing transcripts (Beisang et al. 2012b). CELF1 phosphorylation leads to stabilization and increased expression of GRE-containing mRNAs, consistent with a model whereby transient phosphorylation of CELF1 following T-cell activation leads to the coordinate stabilization and increased expression of a network of transcripts that function to accommodate cellular proliferation and activation during an immune response.

We hypothesize that dysregulation of the GRE/CELF1 network promotes uncontrolled cellular proliferation. In a genetic screen in mice, disruption of CELF1 was found to be a driver of colorectal cancer tumorigenesis (Starr et al. 2009), and CELF1 has been associated with proliferation and abnormal apoptotic responses in malignant cells (Rattenbacher et al. 2010; Gareau et al. 2011; Iakova et al. 2011; Talwar et al. 2013). Abnormal function or expression of CELF1 has been observed in liver cancer (Wang et al. 2008), breast cancer (Arnal-Estapé et al. 2010), and leukemia (Guerzoni et al. 2006). Thus, dysregulation of CELF1 is a potential driver of cancer.

To determine whether dysregulation of the GRE/CELF1 network is found in T-cell malignancies, we compared target transcripts of CELF1 in normal human T cells and malignant T-cell lines. We found that similar sets of GRE-containing transcripts were expressed in normal $\mathrm{T}$ cells and malignant T-cell lines, but the subset of GRE-containing transcripts bound by CELF1 was altered in malignant $T$ cells compared with normal $\mathrm{T}$ cells. In particular, many transcripts that encode regulators of cell proliferation were CELF1 targets in normal T cells, but were not CELF1 targets in malignant $\mathrm{T}$ cells. The decreased binding by CELF1 to these transcripts in malignant $\mathrm{T}$ cells correlated with the phosphorylation of CELF1, as well as increased stability and overexpression of these transcripts. We also analyzed the expression and stability of several of these GRE-containing transcripts that encode growth regulators in cells from patients with primary $\mathrm{T}$-cell leukemia (T-ALL), and found that these transcripts were stabilized and overexpressed in primary T-cell tumors compared with normal $\mathrm{T}$ cells. The increased expression of these regulators of cell growth may facilitate cellular proliferation in malignant T cells.

Surprisingly, we identified a subset of GRE-containing transcripts that were CELF1 targets in malignant $\mathrm{T}$ cells, but not in resting or activated normal $\mathrm{T}$ cells. These transcripts were expressed at lower levels and exhibited more rapid degradation in malignant $\mathrm{T}$-cell lines compared with normal $\mathrm{T}$ cells. These CELF1 targets included numerous transcripts encoding cell cycle suppressors, and down-regulation of their expression in malignant $T$ cells may further elevate cell proliferation. Overall, our data suggest that in malignant $\mathrm{T}$ cells, CELF1 undergoes a change in its RNA-binding behavior such that it loses the ability to bind to a subset of GRE-containing transcripts and gains the ability to bind to another subset. The net effect of this altered CELF1 binding in malignant T cells is predicted to up-regulate the expression of drivers of cell proliferation, down-regulate suppressors of proliferation, and promote a malignant phenotype.

\section{RESULTS}

\section{CELF1 targets in malignant $T$ cells were distinct from CELF1 targets in normal $T$ cells}

CELF1 binds to a network of transcripts that encode important regulators of cell growth and apoptosis, and we hypothesized that the regulation of this network might be altered in malignant T cells. Previously, we performed immunoprecipitation (IP) of CELF1 from T-cell cytoplasmic extracts followed by analysis of coimmunoprecipitated mRNA using Affymetrix microarrays and identified 1309 CELF1 target transcripts in resting normal human $\mathrm{T}$ cells (Beisang et al. 2012b). The same approach was now used to identify target transcripts of CELF1 in the malignant T-cell lines, H9 (Tcell lymphoma), and Jurkat (T-cell leukemia). We found CELF1 associated with 260 probe IDs in H9 T cells and 360 probe IDs in Jurkat T cells, corresponding to 229 and 340 unique mRNA transcripts, respectively. A complete listing of transcripts associated with CELF1 in H9 T cells, Jurkat $\mathrm{T}$ cells, or primary human $\mathrm{T}$ cells is included in Supplemental Table 1. Among these transcripts, 149 were bound by CELF1 in both $\mathrm{H} 9$ and Jurkat malignant T-cell lines. A subset of transcripts that were CELF1 targets in both H9 and Jurkat malignant T-cell lines along with their stability, expression rates, and annotated biological functions is shown in Table 1.

In comparing the CELF1 target transcripts from normal $\mathrm{T}$ cells to CELF1 target transcripts from $\mathrm{H} 9$ or Jurkat malignant T-cell lines, we found relatively little overlap, despite the fact that most of the CELF1 target transcripts expressed in normal $\mathrm{T}$ cells were also expressed in these malignant $\mathrm{T}$-cell lines. Of 1309 CELF1 target transcripts identified in normal T cells, 1044 were expressed in H9 T cells and 1112 were expressed in Jurkat T cells, but only 19 or 21 of these transcripts were found to be CELF1 targets in H9 T cells or Jurkat T cells, respectively, and only 12 were targets of CELF1 in both cell types (Fig. 1A). Thus, in malignant T cells, the lack of binding by CELF1 to most transcripts that were targets in normal $\mathrm{T}$ cells, was not due to absence of those transcripts, but was due to a decreased ability of CELF1 to bind to these transcripts in malignant $\mathrm{T}$ cells. A subset of transcripts that were CELF1 targets in normal T cells but not in the $\mathrm{H} 9$ or Jurkat T-cell lines is shown in Table 2.

To better analyze the relationship between transcript abundance and CELF1 binding in malignant compared with normal T cells, we calculated a fold change in enrichment (FCE) for each transcript on the microarrays defined as 
TABLE 1. Expression and half-lives of GRE-containing transcripts that were CELF1 targets in malignant T cells but not normal T cells

\begin{tabular}{|c|c|c|c|c|c|c|c|c|c|}
\hline RefSeq ID & $\begin{array}{l}\text { Gene } \\
\text { symbol }\end{array}$ & Biological process & T HL $(95 \% \mathrm{Cl})$ & $\begin{array}{l}F C \\
H 9 / T\end{array}$ & $\begin{array}{c}\mathrm{H} 9 \mathrm{HL}(95 \% \\
\mathrm{Cl})\end{array}$ & $\begin{array}{l}\mathrm{FC} \\
\mathrm{JK} / \mathrm{T}\end{array}$ & $\begin{array}{l}\mathrm{JK} \mathrm{KL}(95 \% \\
\mathrm{Cl})\end{array}$ & $\begin{array}{l}\text { FCE } \\
\mathrm{H} 9\end{array}$ & $\begin{array}{l}\text { FCE } \\
\text { JK }\end{array}$ \\
\hline \multicolumn{10}{|c|}{ Cell cycle and apoptosis regulators } \\
\hline NM_001077440 & BCLAF1 & $\begin{array}{c}\text { Regulator of } \\
\text { apoptosis }\end{array}$ & $484(109,777)$ & 0.7 & $290^{\mathrm{a}}(160,440)$ & 0.6 & $306^{\mathrm{a}}(111,324)$ & 2.0 & 1.6 \\
\hline NM_018685 & ANLN & Arrest in mitosis & $316(96,891)$ & 0.7 & $235^{a}(103,373)$ & 0.7 & $86(45,573)$ & 2.1 & 2.1 \\
\hline NM_001130524 & AP1M1 & Cell cycle & $488(421,544)$ & 0.8 & $354^{\mathrm{a}}(65,857)$ & 0.9 & $272^{\mathrm{a}}(56,511)$ & 1.3 & 1.3 \\
\hline NM_001256834 & AURKB & Arrest in mitosis & $359(312,1030)$ & 1.0 & $241^{\mathrm{a}}(48,373)$ & 1.1 & $184^{\mathrm{a}}(47,342)$ & 1.6 & 1.5 \\
\hline NM_001032999 & CBFA2T2 & $\begin{array}{l}\text { Transcription } \\
\text { regulator }\end{array}$ & $300(139,438)$ & 1.1 & $168^{\mathrm{a}}(145,381)$ & 0.8 & $184^{\mathrm{a}}(63,332)$ & 1.6 & 1.2 \\
\hline NM_006733 & CENPI & Mitosis & $640(611,1732)$ & 0.7 & $350^{a}(134,933)$ & 0.8 & $414^{\mathrm{a}}(302,515)$ & 1.9 & 1.8 \\
\hline NM_017882 & CLN6 & Cell death & $1097(885,2878)$ & 0.8 & $694^{\mathrm{a}}(457,770)$ & 0.8 & $152^{\mathrm{a}}(45,741)$ & 2.1 & 2.2 \\
\hline NM_001242481 & EIF1AD & Protein translation & $693(233,1147)$ & 0.7 & $182^{\mathrm{a}}(158,995)$ & 0.6 & $189^{\mathrm{a}}(19,997)$ & 1.5 & 1.6 \\
\hline NM_001184906 & FBXL20 & Arrest in mitosis & $1305(594,1904)$ & 0.6 & $448^{\mathrm{a}}(78,935)$ & 0.8 & $353^{\mathrm{a}}(98,471)$ & 1.8 & 1.3 \\
\hline NM_017769 & G2E3 & $\begin{array}{l}\text { Regulator of } \\
\text { apoptosis }\end{array}$ & $375(301,851)$ & 0.9 & $259^{\mathrm{a}}(109,569)$ & 0.9 & $124^{\mathrm{a}}(69,417)$ & 1.1 & 1.2 \\
\hline NM_001079518 & MED24 & $\begin{array}{l}\text { Transcription } \\
\text { regulator }\end{array}$ & $345(50,639)$ & 0.7 & $129^{\mathrm{a}}(54,296)$ & 0.6 & $213(36,457)$ & 2.2 & 2.5 \\
\hline NM_001003796 & NHP2L1 & S-phase regulation & $390(130,2280)$ & 1.1 & $131(111,297)$ & 0.4 & $212^{\mathrm{a}}(105,698)$ & 1.1 & 1.6 \\
\hline NM_138316 & PANK1 & S-phase regulation & $477(29,2483)$ & 0.7 & $284(43,727)$ & 0.8 & $375(47,996)$ & 2.1 & 2.2 \\
\hline NM_012448 & STAT5B & $\begin{array}{l}\text { Transcription } \\
\text { regulator }\end{array}$ & $678(435,3791)$ & 0.6 & $245^{\mathrm{a}}(220,310)$ & 0.6 & $292^{\mathrm{a}}(50,634)$ & 2.1 & 1.8 \\
\hline NM_001006610 & $\mathrm{SIAH} 1$ & $\begin{array}{l}\text { Negative regulator } \\
\text { of cytokinesis }\end{array}$ & $353(93,1099)$ & 0.7 & $138(90,217)$ & 0.7 & $113^{\mathrm{a}}(28,175)$ & 1.5 & 1.6 \\
\hline NM_018423 & STYK1 & Cell cycle arrest & $642(253,3337)$ & 0.5 & $143^{\mathrm{a}}(58,423)$ & 0.6 & $196^{\mathrm{a}}(99,539)$ & 1.8 & 2.1 \\
\hline NM_000430 & PAFAH1B1 & Arrest in mitosis & $553(431,1107)$ & 0.8 & $89^{\mathrm{a}}(26,797)$ & 0.5 & $108^{\mathrm{a}}(28,593)$ & 1.3 & 1.4 \\
\hline NM_032354 & TMEM107 & Apoptosis & $689(218,1296)$ & 0.4 & $295^{\mathrm{a}}(74,667)$ & 0.5 & $377^{\mathrm{a}}(91,738)$ & 1.5 & 1.3 \\
\hline \multicolumn{10}{|c|}{ Cellular metabolism regulators } \\
\hline NM_018686 & CMAS & Metabolism & $922(719,1875)$ & 0.2 & $456(311,532)$ & 0.2 & $203^{\mathrm{a}}(109,615)$ & 1.3 & 1.4 \\
\hline NM_147190 & CERS5 & Lipid metabolism & $898(28,1132)$ & 0.8 & $399^{\mathrm{a}}(75,473)$ & 0.7 & $236^{a}(102,529)$ & 2.0 & 2.2 \\
\hline NM_024345 & DCAF10 & $\begin{array}{l}\text { Protein } \\
\quad \text { ubiquitination }\end{array}$ & $514(54,882)$ & 0.7 & $217(64,898)$ & 0.7 & $359^{\mathrm{a}}(96,524)$ & 2.1 & 2.0 \\
\hline NM_032138 & KBTBD7 & Protein metabolism & $593(416,1129)$ & 0.8 & $219(39,350)$ & 0.8 & $283(26,592)$ & 1.5 & 1.6 \\
\hline NM_005723 & TSPAN5 & Motility & $349(126,624)$ & 0.8 & $233^{\mathrm{a}}(52,701)$ & 0.7 & $145^{\mathrm{a}}(72,656)$ & 1.2 & 1.6 \\
\hline NM_014820 & TOMМ70A & Protein transport & $187(19,693)$ & 0.8 & $77^{\mathrm{a}}(14,207)$ & 0.7 & $171^{\mathrm{a}}(34,204)$ & 1.3 & 1.2 \\
\hline NM_001195677 & VAPB & Vesicle transport & $748(202,3698)$ & 0.5 & $126^{\mathrm{a}}(14,267)$ & 0.9 & $394^{\mathrm{a}}(95,907)$ & 1.4 & 1.3 \\
\hline NM_007187 & WBP4 & Metabolism & $137(89,687)$ & 0.9 & $103(18,267)$ & 0.4 & $170^{\mathrm{a}}(46,486)$ & 1.7 & 1.8 \\
\hline
\end{tabular}

(RefSeq ID) Reference sequence annotated in NCBI; (Biological process) annotated in NCBI; (T) T cells; (JK, H9) Jurkat or H9 cells; (HL) median half-life; $(\mathrm{Cl})$ confidence interval as measured by microarrays (as described in Materials and Methods); (FC) fold change; (FCE) fold change in enrichment.

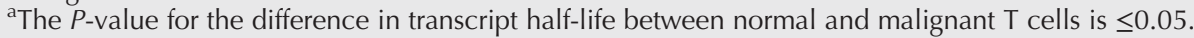

\section{$\mathrm{FCE}=(\mathrm{CELF} 1 \cdot \mathrm{IP} /$ Input $)$ malignant $/(\mathrm{CELF} 1$ \\ . IP/input) normal,}

where the ratio of the microarray signal from the CELF1 IP to the microarray signal from input RNA for malignant $\mathrm{T}$ cells was divided by the same ratio for normal $\mathrm{T}$ cells. The FCE for all CELF1 target transcripts expressed in H9 or Jurkat T cells is included in Supplemental Table 1. The average FCE for all transcripts was 1.03 and 1.04 for $\mathrm{H} 9$ and Jurkat $\mathrm{T}$ cells, respectively, indicating that the overall distribution of transcripts with respect to CELF1 binding did not change when comparing malignant to normal $\mathrm{T}$ cells. In contrast, the average FCE of transcripts that were CELF1 targets in normal $\mathrm{T}$ cells, were 0.65 and 0.71 for $\mathrm{H} 9$ and Jurkat $\mathrm{T}$ cells, respectively, indicating that CELF1 exhibited decreased binding to target transcripts in both malignant cell lines (Fig. 1B,C; Tc, hashed bars). Thus, correcting for transcript abundance in malignant T-cell lines compared with normal $\mathrm{T}$ cells indicated that the lack of association of CELF1 with these target transcripts in malignant $\mathrm{T}$ cells could not be explained by the absence of these transcripts, but was more readily explained by an inability of CELF1 to bind to those transcripts. Table 2 shows decreased FCE values for a subset of transcripts that were CELF1 targets in normal T cells but not $\mathrm{H} 9$ or Jurkat $\mathrm{T}$ cells, even though they were expressed in each cell type.

Interestingly, the average FCE for transcripts that were CELF1 binding targets in malignant T-cell lines were 1.42 and 1.43 in $\mathrm{H} 9$ and Jurkat T-cell lines, respectively (Fig. 1B,C: H9 and JK, empty bars). Table 1 shows the increased 

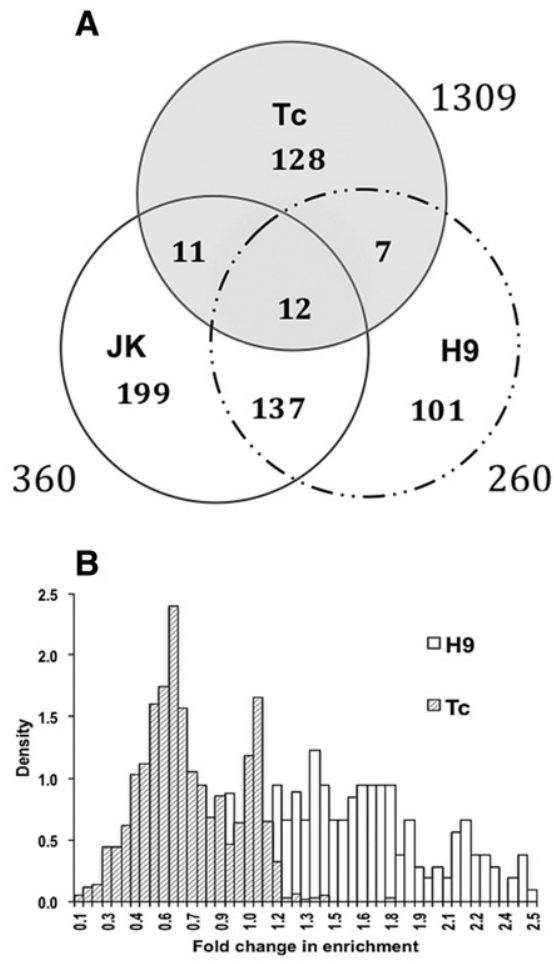

C

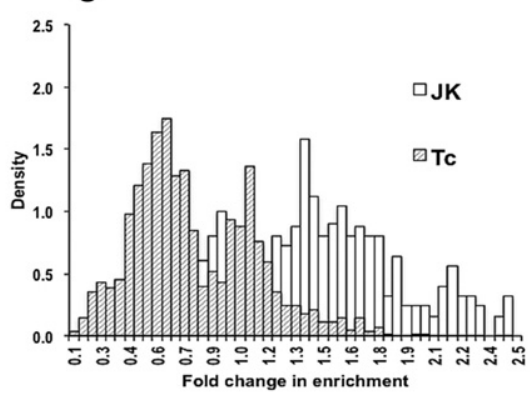

FIGURE 1. (A) Distinct CELF1 targets in normal and malignant $\mathrm{T}$ cells. The Venn diagram shows the number of transcripts identified in the CELF1 IP from normal T cells (Tc), H9 T cells (H9), and Jurkat T cells (JK). $(B, C)$ Altered association of CELF1 with target transcripts in malignant $\mathrm{T}$ cells compared with normal $\mathrm{T}$ cells. For H9 $(B)$ and Jurkat $(C)$ T-cell lines, the fold change in enrichment (FCE) was calculated as described in the text. Histograms showing the distribution of these values are depicted for CELF1 target transcripts in normal $\mathrm{T}$ cells ( $\mathrm{Tc}$, hatched gray bars) and $\mathrm{H} 9$ or Jurkat (JK) malignant $\mathrm{T}$ cells (empty bars). For each group of histograms, density on the $y$-axis is the normalized number of transcripts falling in a given FCE bin.

FCE values for a subset of the transcripts that were CELF1 targets in malignant $\mathrm{T}$-cell lines. These data suggest that CELF1 could not bind to these transcripts in normal $\mathrm{T}$ cells, even though they were present in cytoplasm, but gained an ability to bind to these transcripts in malignant $\mathrm{T}$ cells. These results in malignant $\mathrm{T}$ cells are quite different from what we previously observed in normal activated $\mathrm{T}$ cells (Beisang et al. 2012b), where T-cell activation led to a similar decrease in binding by CELF1 to target transcripts from rest- ing T cells, but CELF1 did not gain an ability to bind to a new subset of transcripts. Overall, we observed that binding by CELF1 to target transcripts was altered in malignant $\mathrm{T}$ cells compared with normal $\mathrm{T}$ cells, and CELF1 in malignant $\mathrm{T}$ cells gained an ability to bind to a new subset of target transcripts.

\section{Normal and malignant $T$ cells express similar amounts of CELF1, but with different phosphorylation patterns}

We performed Western blot assays to assess the level of expression of the CELF1 protein in cytoplasmic extracts from resting normal $\mathrm{T}$ cells, normal $\mathrm{T}$ cells that were stimulated for $6 \mathrm{~h}$ with anti-CD3 and anti-CD28 antibodies, and Jurkat or $\mathrm{H} 9$ malignant $\mathrm{T}$ cells, and we found similar levels of expression in each cell type or condition (Fig. 2A, CELF1 and Fig. 2B, left). CELF1 is known to be regulated through phosphorylation following T-cell activation (Beisang et al. 2012b), but CELF1 has 22 potential phosphorylation sites (PhosphoSitePlus database, Cell Signaling Technology), and the sites of phosphorylation following T-cell activation are not known. To screen for phosphorylation of CELF1 in malignant T cells, we blotted the same membranes with a commercially available antibody directed at a serine 28 phosphopeptide from CELF1 (Fig. 2A, Phospho-S28 CELF1 and Fig. 2B, right). We found only low levels of phosphorylation at S28 in normal resting T cells (rTc,) and normal stimulated T cells (sTc), but much higher levels in $\mathrm{H} 9$ and Jurkat (JK) malignant T cells, indicating that phosphorylation of CELF1 at this site differed between resting or activated normal $\mathrm{T}$ cells and these malignant $\mathrm{T}$-cell lines.

To further characterize CELF1 phosphorylation in normal and malignant $\mathrm{T}$ cells, we performed two-dimensional (2D) gel electrophoresis, followed by Western blotting with an anti-CELF1 antibody (Fig. 3). As seen previously, CELF1 was not phosphorylated in normal resting $\mathrm{T}$ cells $(\mathrm{rTc})$, with the main position of the signal localized near $\mathrm{pH} 8.7$, and stimulation of normal T cells with anti-CD3 and antiCD28 antibodies caused the CELF1 signal to shift toward the right ( $\mathrm{pH}$ 3.0), indicating phosphorylation of CELF1 (Fig. 3, sTc). In H9 and Jurkat T cells, however, CELF1 exhibited a much more complex phosphorylation pattern with even further shift of the CELF1 signal to the right, demonstrating that CELF1 was hyperphosphorylated in the malignant T-cell lines compared with stimulated normal $\mathrm{T}$ cells.

Treatment of cytoplasmic extracts from $\mathrm{H} 9$ or Jurkat $\mathrm{T}$ cells with $\lambda$-phosphatase (LPP+) led to a shift of the CELF1 signal toward the unphosphorylated position, as was seen previously in cytoplasmic extracts from normal stimulated T cells (Beisang et al. 2012b). Overall, these results demonstrate that CELF1 is hyperphosphorylated in malignant $\mathrm{T}$ cells compared with normal stimulated $\mathrm{T}$ cells, with complex phosphorylation patterns suggesting multiple sites of phosphorylation. 
TABLE 2. Expression and half-lives of GRE-containing transcripts that were CELF1 targets in normal T cells but not malignant T cells

\begin{tabular}{|c|c|c|c|c|c|c|c|c|c|}
\hline $\begin{array}{l}\text { RefSeq } \\
\text { Transcript ID }\end{array}$ & $\begin{array}{l}\text { Gene } \\
\text { Symbol }\end{array}$ & Biological process & $\begin{array}{c}\text { T HL } \\
(95 \% \mathrm{Cl})\end{array}$ & $\begin{array}{c}\mathrm{FC} \\
\mathrm{H} 9 / \mathrm{T}\end{array}$ & $\mathrm{H} 9 \mathrm{HL}(95 \% \mathrm{Cl})$ & $\begin{array}{l}\mathrm{FC} \\
\mathrm{JK} / \mathrm{T}\end{array}$ & JK HL $(95 \% \mathrm{Cl})$ & $\begin{array}{l}\text { FCE } \\
\mathrm{H} 9\end{array}$ & $\begin{array}{l}\text { FCE } \\
\text { JK }\end{array}$ \\
\hline \multicolumn{10}{|c|}{ Cell growth and motility } \\
\hline NM_001017415 & USP1 & $\begin{array}{l}\text { Protein } \\
\quad \text { ubiquitination }\end{array}$ & $49(18,80)$ & 1.6 & $156^{\mathrm{a}}(49,262)$ & 1.6 & $581^{\mathrm{a}}(184,1881)$ & 0.43 & 0.36 \\
\hline NM_000462 & UBE3A & $\begin{array}{l}\text { Protein } \\
\quad \text { ubiquitination }\end{array}$ & $67(46,139)$ & 1.5 & $346^{\mathrm{a}}(246,746)$ & 1.7 & $1511^{\mathrm{a}}(586,6560)$ & 0.64 & 0.70 \\
\hline NM_001017371 & SP3 & $\begin{array}{l}\text { Transcription } \\
\text { regulator }\end{array}$ & $70(14,126)$ & 1.6 & $186(55,316)$ & 1.5 & $627^{\mathrm{a}}(241,2987)$ & 0.44 & 0.51 \\
\hline NM_012197 & RABGAP1 & $\begin{array}{l}\text { RAB GTPase } \\
\text { activating protein } \\
1\end{array}$ & $91(12,168)$ & 1.5 & $638^{\mathrm{a}}(279,2056)$ & 1.5 & $616^{\mathrm{a}}(408,3741)$ & 0.47 & 0.44 \\
\hline NM_005028 & PIP4K2A & $\begin{array}{l}\text { Cytoskeleton } \\
\text { signaling }\end{array}$ & $119(34,204)$ & 1.5 & $454(69,2839)$ & 1.4 & $1235^{\mathrm{a}}(148,3518)$ & 0.48 & 0.57 \\
\hline NM_002806 & PSMC6 & $\begin{array}{l}\text { Protein } \\
\text { ubiquitination }\end{array}$ & $88(55,132)$ & 1.8 & $259^{\mathrm{a}}(25,843)$ & 1.9 & $717^{\mathrm{a}}(334,4900)$ & 0.52 & 0.50 \\
\hline NM_005542 & INSIG1 & $\begin{array}{l}\text { Insulin induced } \\
\text { gene } 1\end{array}$ & $86(53,140)$ & 1.7 & $124^{\mathrm{a}}(87,336)$ & 1.5 & $788^{\mathrm{a}}(378,5455)$ & 0.52 & 0.53 \\
\hline NM_006496 & GNAI3 & $\begin{array}{l}\text { Cytoskeleton } \\
\text { signaling }\end{array}$ & $98(30,1249)$ & 1.7 & $547^{\mathrm{a}}(42,2135)$ & 1.5 & $1081^{\mathrm{a}}(93,1405)$ & 0.45 & 0.48 \\
\hline NM_012297 & G3BP2 & Scaffold protein & $130(98,501)$ & 1.5 & $509^{\mathrm{a}}(81,358)$ & 1.4 & $654^{\mathrm{a}}(131,2620)$ & 0.44 & 0.42 \\
\hline NM_012300 & FBXW11 & $\begin{array}{l}\text { Transcription } \\
\text { regulator }\end{array}$ & $71(8,134)$ & 1.4 & $366^{\mathrm{a}}(88,820)$ & 1.5 & $146^{a}(76,3603)$ & 0.50 & 0.54 \\
\hline NM_001193416 & DDX3X & $\begin{array}{l}\text { Translation } \\
\text { regulator }\end{array}$ & $80(15,145)$ & 1.5 & $472^{\mathrm{a}}(117,1061)$ & 1.5 & $459^{\mathrm{a}}(302,2221)$ & 0.41 & 0.49 \\
\hline NM_001127192 & CNBP & $\begin{array}{l}\text { Transcription } \\
\text { regulator }\end{array}$ & $69(16,121)$ & 2.0 & $346^{\mathrm{a}}(99,1306)$ & 1.8 & $477^{\mathrm{a}}(90,1345)$ & 0.39 & 0.41 \\
\hline NM_014918 & CHSY1 & $\begin{array}{l}\text { Cytoskeleton } \\
\text { signaling }\end{array}$ & $64(31,131)$ & 1.5 & $146^{\mathrm{a}}(66,227)$ & 1.5 & $3614^{\mathrm{a}}(441,8067)$ & 0.63 & 0.58 \\
\hline NM_005194 & CEBPB & $\begin{array}{l}\text { Transcription } \\
\text { regulator }\end{array}$ & $58(23,94)$ & 1.4 & $88(27,150)$ & 1.4 & $229^{\mathrm{a}}(58,815)$ & 0.57 & 0.60 \\
\hline NM_001838 & CCR7 & $\begin{array}{l}\text { Chemokine } \\
\text { receptor }\end{array}$ & $83(27,138)$ & 1.2 & $229^{\mathrm{a}}(72,529)$ & 1.3 & $372^{\mathrm{a}}(124,1068)$ & 0.52 & 0.55 \\
\hline NM_001008540 & CXCR4 & $\begin{array}{l}\text { Chemokine } \\
\text { receptor }\end{array}$ & $61(30,92)$ & 1.4 & $49(31,67)$ & 1.5 & $271^{\mathrm{a}}(28,571)$ & 0.46 & 0.33 \\
\hline \multicolumn{10}{|c|}{ Cell stress and cell survival } \\
\hline NM_006948 & HSPA13 & $\begin{array}{l}\text { Heat shock } \\
\text { response }\end{array}$ & $90(3,182)$ & 1.2 & $280^{\mathrm{a}}(161,722)$ & 1.5 & $319^{a}(114,507)$ & 0.50 & 0.37 \\
\hline NM_003574 & VAPA & $\begin{array}{l}\text { Vesicle assembly } \\
\text { protein }\end{array}$ & $86(19,153)$ & 1.4 & $332^{\mathrm{a}}(90,753)$ & 1.4 & $760^{\mathrm{a}}(596,1107)$ & 0.55 & 0.59 \\
\hline NM_001010989 & HERPUD1 & $\begin{array}{l}\text { Stress-inducible } \\
\text { protein }\end{array}$ & $133(29,298)$ & 1.4 & $79(37,320)$ & 1.4 & $331^{\mathrm{a}}(117,1834)$ & 0.42 & 0.39 \\
\hline NM_019058 & DDIT4 & $\begin{array}{l}\text { DNA-damage- } \\
\text { inducible }\end{array}$ & $50(11,89)$ & 1.7 & $738^{\mathrm{a}}(528,3248)$ & 1.5 & $127^{\mathrm{a}}(79,432)$ & 0.46 & 0.50 \\
\hline NM_005038 & PPID & $\begin{array}{l}\text { Oxidative stress } \\
\text { response protein }\end{array}$ & $67(35,99)$ & 1.4 & $437^{\mathrm{a}}(102,749)$ & 1.4 & $445^{\mathrm{a}}(288,1199)$ & 0.41 & 0.45 \\
\hline
\end{tabular}

(RefSeq ID) Reference sequence annotated in NCBI; (Biological process) annotated in NCBI; (T) T cell; (JK, H9) Jurkat or H9 cells; (HL) median half-life; $(\mathrm{Cl})$ confidence interval, as measured by microarrays; $(\mathrm{FC})$ fold change; (FCE) fold change in enrichment.

${ }^{a}$ The $P$-value for the difference in transcript half-life between normal and malignant T cells is $\leq 0.05$.

\section{Loss of binding by CELF1 to a subset of target transcripts in malignant $T$ cells correlated with CELF1 phosphorylation and transcript stabilization}

To test more directly whether the phosphorylation of CELF1 in malignant T-cell lines influenced RNA binding, we immunopurified CELF1 from cytoplasmic lysates from normal and malignant $\mathrm{T}$ cells and assessed CELF1 binding to a riboprobe containing a GRE or mutant GRE (Fig. 4A with graphical representation in Fig. 4B). CELF1 immunopurified from both malignant $\mathrm{T}$-cell lines showed reduced binding to the GRE-riboprobe compared to CELF1 derived from normal resting $\mathrm{T}$ cells (cf. lanes 5 and 9 to lane 1 ). Treatment with LPP resulted in an increase in binding to the GRE-containing riboprobe by CELF1 immunopurified from malignant T-cell lines (cf. lane 5 to lane 7 and lane 9 to lane 11). In contrast, binding by CELF1 immunopurified from resting human $\mathrm{T}$ cells was unaffected by LPP treatment (cf. lanes 1 and 3 ). 
A

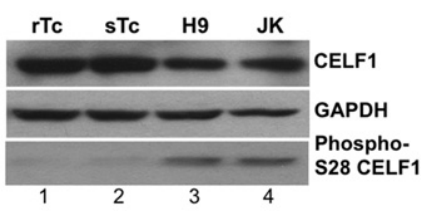

B

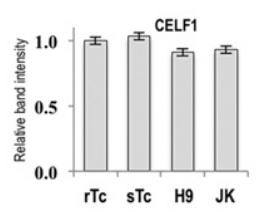

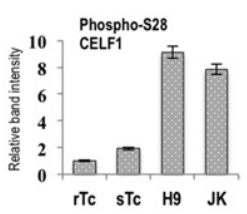

FIGURE 2. The levels of CELF1 and phopho-S28 CELF1 expression in normal and malignant $\mathrm{T}$ cells. (A) Cytoplasmic extracts were prepared from resting normal T cells (rTc), normal T cells that had been stimulated for $6 \mathrm{~h}$ with anti-CD3 and CD28 antibodies (sTc), H9 T cells, or Jurkat (JK) T cells. Equal amounts of cytoplasmic protein from each cell type were separated by SDS-polyacrylamide gel electrophoresis and the gels were blotted onto PVDF membranes which were probed with an anti-CELF1 antibody, an anti-phopho-S28 CELF1 antibody, and an anti-GAPDH antibody (loading control). (B) The experiment shown in $A$ was performed three times and the images were quantified using Image J. For each experiment, the density of each CELF1 band or phospho-S28 CELF1 band was normalized to the density of the corresponding GAPDH band, and the average normalized densities were graphed. The error bars represent the \pm SE for each average value.

These results suggest that the binding by CELF1 to the GREriboprobe was inhibited in malignant $\mathrm{T}$ cells due to phosphorylation, and binding was restored when CELF1 was de-phosphorylated in vitro.

We previously measured mRNA decay rates on a genomewide basis in normal $\mathrm{T}$ cells and the Jurkat and $\mathrm{H} 9$ malignant T-cell lines (Vlasova et al. 2005), and we now compared transcript half-lives across these cell types (see Supplemental Table 1). We found that most transcripts that were CELF1 targets in normal T cells, but were not CELF1 targets in H9 or Jurkat $\mathrm{T}$ cells, were stabilized in the malignant $\mathrm{T}$-cell lines. For example, of the 113 short-lived CELF1 target transcripts with median half-lives $\leq 90 \mathrm{~min}$ in normal T cells, 106 (93\%) and $104(92 \%)$ were stabilized in H9 and Jurkat T-cell lines, respectively $(P \leq 0.05)$. None of these stabilized transcripts were CELF1 targets in malignant T-cell lines. The mRNA decay rates of a subset of these transcripts that were CELF1 targets in normal $\mathrm{T}$ cells but not in malignant $\mathrm{T}$-cell lines are shown in Table 2: All of them were stabilized $(P \leq 0.05)$ in malignant $\mathrm{T}$ cells compared with normal $\mathrm{T}$ cells. Our results suggest that CELF1 phosphorylation in malignant $\mathrm{T}$ cells leads to decreased CELF1 binding to GU-rich containing RNA transcripts, that were CELF1 targets in normal T cells, resulting in transcript stabilization in malignancy.

\section{CELF1 targets in malignant T-cell lines exhibited accelerated $m R N A$ degradation}

Since binding by CELF1 is known to correlate with faster mRNA turnover (Vlasova et al. 2008), we evaluated the decay of transcripts that were CELF1 targets in malignant $\mathrm{T}$ cells but were not CELF1 targets in normal $\mathrm{T}$ cells. Compared with normal $\mathrm{T}$ cells, the decay rates of most CELF1 targets in malignant $\mathrm{T}$ cells were significantly shorter. Table 1 shows half-life values for a subset of transcripts that were CELF1 targets in both $\mathrm{H} 9$ and Jurkat $\mathrm{T}$ cells, and all of these transcripts decayed significantly faster in malignant compared with normal T cells. Overall, our results suggested that CELF1 gained

the ability to bind to a distinct subset of transcripts in malignant $\mathrm{T}$ cells, and this binding correlated with accelerated mRNA degradation.

To verify the relationship between CELF1 binding and mRNA decay that we found in our microarray data, we selected transcripts that were differentially bound to CELF1 in normal $\mathrm{T}$ cells and malignant $\mathrm{T}$-cell lines to perform confirmatory assays (Fig. 5). Cytoplasmic lysates from normal $\mathrm{T}$ cells $(\mathrm{Tc}), \mathrm{H} 9 \mathrm{~T}$ cells (H9), and Jurkat T cells (JK) were immunoprecipitated with no antibody (input, I), an anti-CELF1 antibody (C), an anti-poly(A) binding protein antibody $(\mathrm{P})$ as a positive control, and an anti-HA antibody $(\mathrm{H})$ as a negative control, and copurified RNA was isolated. This RNA was evaluated by reverse transcriptase PCR (RT-PCR) using transcript-specific primers (see Supplemental Table 2) to measure the binding by CELF1 to select transcripts (Fig. 5, left panels). Normalized quantified results for the intensity of the CELF1 IP band for each transcript are shown in Figure 5, middle panels. We also used quantitative real-time PCR (QPCR) to measure mRNA decay rates of these same transcripts after treatment of cells with Actinomycin D (Fig. 5, right panels) and determined if CELF1 binding correlated with mRNA decay.

The IP results confirmed that the AURKB, KBTBD7 and SIAH1 transcripts were enriched in the anti-CELF1 immunoprecipitates from malignant $\mathrm{T}$ cells compared with normal $\mathrm{T}$ cells (Fig. 5, left and middle panels), and half-lives of these transcripts in $\mathrm{H} 9$ and Jurkat cells were significantly shorter, with $P \leq 0.05$ for each transcript (Fig. 5, right panels).

In contrast, the CEBPB, EIFEBP2, TNFSF10 transcripts were enriched in the anti-CELF1 immunoprecipitates from

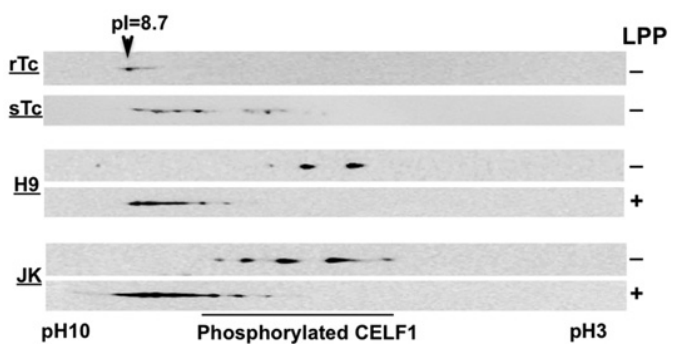

FIGURE 3. The CELF1 phosphorylation pattern differs in malignant $\mathrm{T}$ cells compared with normal stimulated $\mathrm{T}$ cells. Cytoplasmic lysates were prepared from normal resting $\mathrm{T}$ cells $(\mathrm{rTc})$, normal $\mathrm{T}$ cells that were stimulated for $6 \mathrm{~h}$ with anti-CD3 and anti-CD28 antibodies (sTc), H9 T cells (H9), and Jurkat (JK) T cells. The lysates were treated with $\lambda$-protein phosphatase (LPP + ) or mock-treated (LPP -). Samples were then separated by two-dimensional gel electrophoresis, and CELF1 was identified by Western blot analysis as described in Materials and Methods. The arrow represents the position of migration of the unphosphorylated form of CELF1, localized at $\mathrm{pH}$ 8.7. The results are representative of four independent experiments. 
normal $\mathrm{T}$ cells compared with malignant $\mathrm{T}$ cells, and these transcripts decayed more rapidly in normal $\mathrm{T}$ cells compared with malignant $\mathrm{T}$-cell lines $(P \leq 0.05$ for each transcript). These results confirm that CELF1 target transcripts exhibited accelerated decay, and CELF1 binding correlates with more rapid mRNA turnover, suggesting that altered CELF1 binding contributes to abnormal mRNA decay in malignant $\mathrm{T}$ cells.

\section{GU-rich sequences were enriched in CELF1 target transcripts in malignant T-cell lines}

CELF1 binds to GU-rich RNA sequences (for review, see Beisang et al. 2012a). We evaluated CELF1 target transcripts in malignant $\mathrm{T}$ cells to determine whether they contained defined CELF1 binding sequences. As described in Materials and Methods, a de novo motif search using Partek Genomic Suite software identified enrichment of G/UU-containing sequences in the $3^{\prime}$ UTR of CELF1 target transcripts from malignant T-cell lines (see motif logo in Supplemental Fig. 1). The top two consensus sequences within this group of transcripts resembled the GRE. These results suggest that CELF1 in malignant $\mathrm{T}$ cells interacts with target transcripts through GRE sequences that are similar to known CELF1 target sequences in normal $\mathrm{T}$ cells and other cell types (Halees et al. 2011).

\section{CELF1 targets in malignant T cells encode components of cell cycle networks}

In normal T cells, CELF1 targets encode a variety of regulators of apoptosis and post-transcriptional regulatory networks (Beisang et al. 2012b). Since the subset of CELF1 target transcripts in malignant $\mathrm{T}$ cells is distinct from the subset of CELF1 targets in normal T cells, we analyzed the functions of the CELF1 target transcripts identified in H9 and Jurkat $\mathrm{T}$ cells. The most highly enriched CELF1 target transcripts in $\mathrm{H} 9$ and Jurkat malignant $\mathrm{T}$-cell lines are listed in Table 1, and the proteins encoded by these transcripts function as cell cycle and apoptosis regulators or regulators of metabolism.

We evaluated biological processes and molecular functions for CELF1 target transcripts in H9 or Jurkat T cells, and found enrichment of a cluster of mRNAs encoding proteins with roles in cell cycle regulation. A simplified regulatory network of cell cycle control proteins encoded by GRE-containing CELF1 targets in malignant $\mathrm{T}$ cells is shown in Figure 6. This network shows CELF1 target transcripts that regulate cell cycle progression throughout the G1, S, G2, and M phases, including genes that are expressed at higher levels during G1/S and G2/M cell cycle checkpoints (Ingenuity Knowledge Database) and components of cyclin-driven pathways that play important roles in cell development, differentiation, and tumorigenesis (Pathways Analysis, Ingenuity Systems). Many of the transcripts shown are known to be abnormally expressed in cancer. Among them are regulators of DNA transcription and replication: NDRG3 (Yang et al. 2013), STAT5B (Darvin et al. 2013), CENPF (Lokody 2014), G2E3 (Crawford and Piwnica-Worms 2001), ZNF436 (Li et al. 2006), ZNF678 (http://www.proteinatlas.org/search/), ZMAT3 (Parikh et al. 2014), AP2A2 (Ting et al. 2012), MED24 (Bemmo et al. 2010); and proteins that control cellular senescence and mitotic arrest (JUND [Hernandez et al. 2008], TERF2 [McDaniel et al. 2006], NGR3, CENPA [Valdivia et al. 2009], PAFAH1B1 [Zimdahl et al. 2014], CDK11A/B [Hu et al. 2007; Choi et al. 2014]), negative regulators of G1 phase and G1/S transition (CDK1 [Roy et al. 2010], ZNF346, CDC73 [Hahn et al. 2012]) and cytokinesis (SIAH1 [Kramer et al. 2013], AURKB [Goldenson and Crispino 2014]). A functional analysis (Table 3) showed that CELF1 targets in malignant T cells were linked to cancer, neurological diseases, and developmental abnormalities in the category of diseases and disorders. In the category of molecular and cellular function, CELF1 targets were linked to cell cycle, cellular organization, and cell death and survival. In the category of physiological system development and function, CELF1 targets were linked to abnormal tumor morphology. In summary, our analysis suggested that the
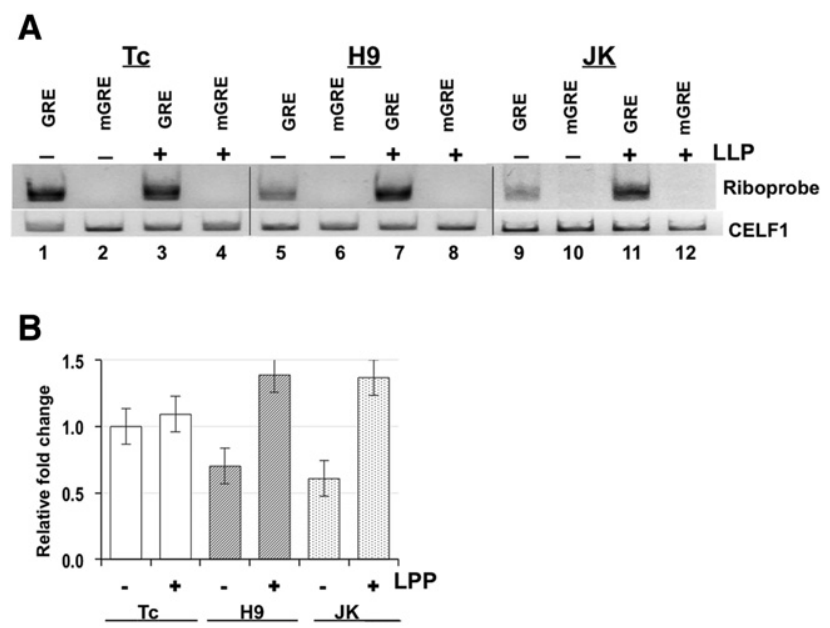

FIGURE 4. Dephosphorylation of CELF1 improves its in vitro binding to a GRE-riboprobe. (A) CELF1 protein was immunopurified on agarose beads from cytoplasmic extracts ( $100 \mu \mathrm{g}$ of protein) from normal resting T cells (Tc), H9 T cells, or Jurkat (JK) T cells that were treated with either $\lambda$-protein phosphatase $(\mathrm{LPP}+)$ or mock-treated (LPP -). A biotinylated 35-nt GRE-riboprobe (GRE) or a mutated GRE RNA riboprobe (mGRE) was mixed with immunopurified CELF1. Complexes were then UV-crosslinked, separated by SDS electrophoresis, and transferred onto a nylon membrane. CELF1 binding to the biotinylated RNA riboprobe was visualized by probing the membrane with labeled streptavidin (top panel, Riboprobe). Subsequently, the same membranes were probed with an anti-CELF1 antibody to determine the amount of total CELF1 protein immunopurified on beads (bottom panel, CELF1). (B) The experiment shown in $A$ was performed four times. In each experiment the amount of bound riboprobe signal in each lane was normalized to the corresponding signal for total CELF1 protein. For lanes where the GRE-riboprobe was used, LPP+ signal was normalized to relative LPP - signal for bound riboprobe and graphed as the average and \pm SE from each condition. 


\section{AURKB}
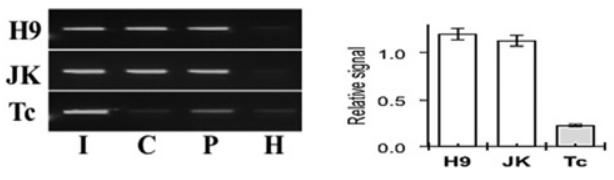

KBTBD7
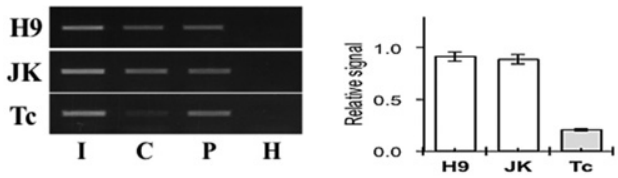

SIAH1
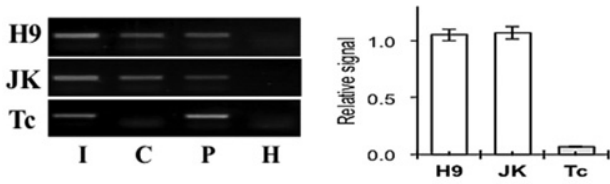

CEBPB
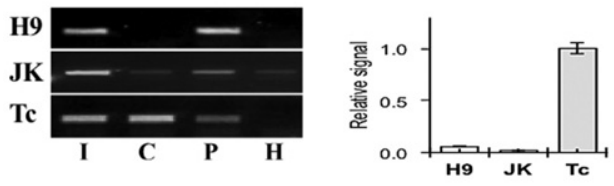

EIFEBP2
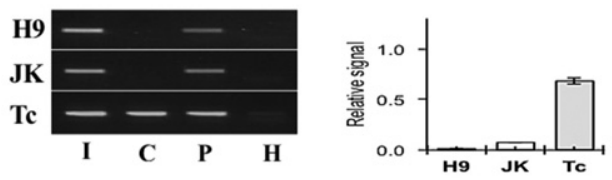

TNFRSF10
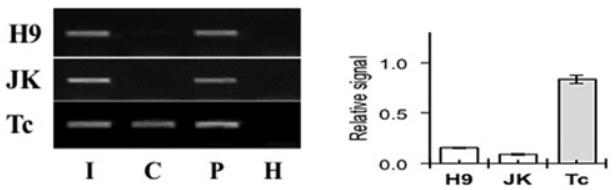
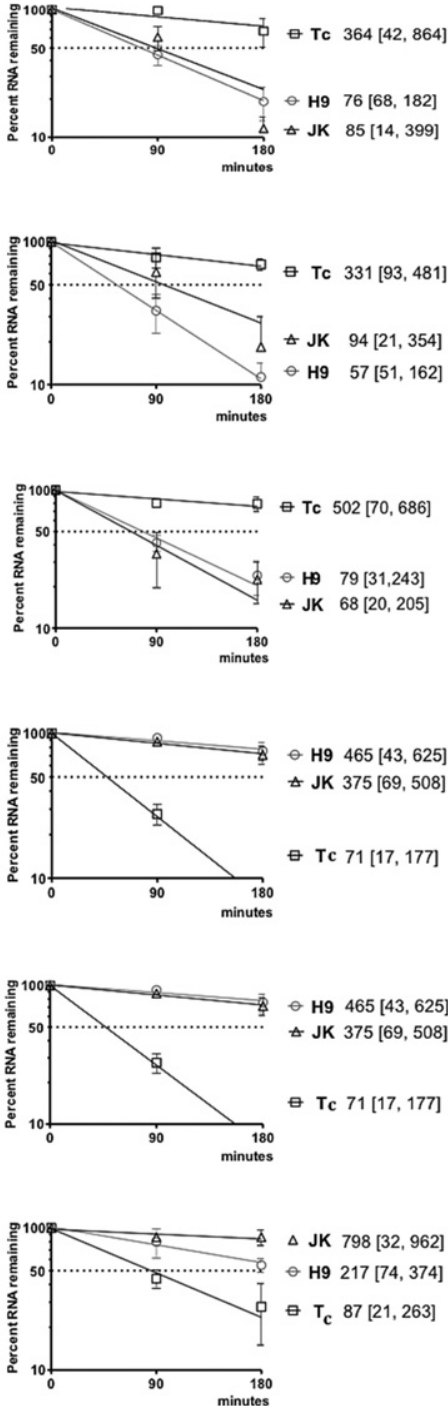

FIGURE 5. Binding by CELF1 is associated with mRNA destabilization. (Left) Cytoplasmic lysates were prepared from normal T cells (Tc), H9 T cells (H9), and Jurkat T cells (JK), and material from these lysates was immunoprecipitated on beads coated with an anti-CELF1 antibody (C), an anti-Hemagglutinin antibody $(\mathrm{H})$, or an anti-poly(A) binding protein antibody (P). RNA isolated from the input cytoplasmic lysates (I) and the immunoprecipitated material was analyzed by reverse transcription PCR using transcript-specific primers to amplify the indicated transcripts. (Middle) The experiment shown in $A$ was performed three times, and band intensities were determined using Image J. For each band, the intensity of the corresponding HA $(\mathrm{H})$ band was subtracted, and then the CELF1 (C) signal was normalized to the PABP (P) signal for each transcript. The normalized relative signal intensity of the CELF1 band was graphed for each transcript in each cell line as the average signal and \pm standard error, SE, from three experiments. (Right) Real-time quantitative PCR was used to measure the half-lives of the transcripts shown in $A$ and $B$ in normal and malignant $\mathrm{T}$ cells. Actinomycin $\mathrm{D}$ was added to primary human T cells (T), H9 or Jurkat (JK) T-cell cultures, and total cellular RNA was harvested at $0-, 90-$, and 180-min time points. mRNA levels were measured by quantitative real-time PCR using transcript-specific primers, and transcript levels were normalized to the level of the HPRT transcript. The normalized level of each transcript was set at $100 \%$ at time zero, and the other time points were graphed relative to that value using Graph Prism Software. Each point represents the mean and standard error of the mean from three or four independent experiments. To the right of the graph, the mean half-life (in minutes) and 95\% confidence interval is shown for each transcript in each cell type. abnormal function of CELF1 in malignant $\mathrm{T}$ cells leads to misexpression of a network of GRE-containing transcripts.

\section{Coordinate stabilization and up-regulation of CELF1 target transcripts in primary T-ALL}

We found that numerous short-lived CELF1 target transcripts in normal $\mathrm{T}$ cells were not CELF1 targets in malignant T-cell lines, and the lack of CELF1 binding correlated with transcript stabilization. To determine whether stabilization of these same transcripts also occurred in primary T-cell tumors, we measured transcript levels and decay rates of 17 mRNA transcripts in primary $\mathrm{T}$ acute lymphoblastic leukemia (T-ALL) cells (Table 4). These mRNAs were CELF1 targets in normal $\mathrm{T}$ cells but were not CELF1 targets in $\mathrm{H} 9$ or Jurkat $\mathrm{T}$ cells. Actinomycin D was added to primary T-cell tumor cells isolated from peripheral blood from four T-ALL patients, normal human $\mathrm{T}$ cells from four donors, and $\mathrm{H} 9 \mathrm{~T}$ cells or Jurkat $\mathrm{T}$ cells from three independent cell passages; mRNA decay rates were measured using QRTPCR. The QRT-PCR results confirmed our microarray data: transcripts that were CELF1 targets in normal $\mathrm{T}$ cells but not in $\mathrm{H} 9$ or Jurkat T cells, were stabilized and up-regulated in these T-cell lines. Furthermore, we found that these same transcripts were also stabilized and up-regulated in primary T-ALL cells (Table 4). These results support our hypothesis that a subset of GRE-containing transcripts is stabilized and up-regulated in primary human T-ALL tumors likely due to escape from CELF1-mediated degradation.

\section{DISCUSSION}

We found that the GRE/CELF1 network, which normally functions to coordinate cellular proliferation during the course of normal T-cell activation, is dysregulated in malignant $\mathrm{T}$ cells. Altered binding by CELF1 to target transcripts in malignant $\mathrm{T}$ cells led to abnormal stabilization of a network of transcripts that promote cell proliferation and abnormal 


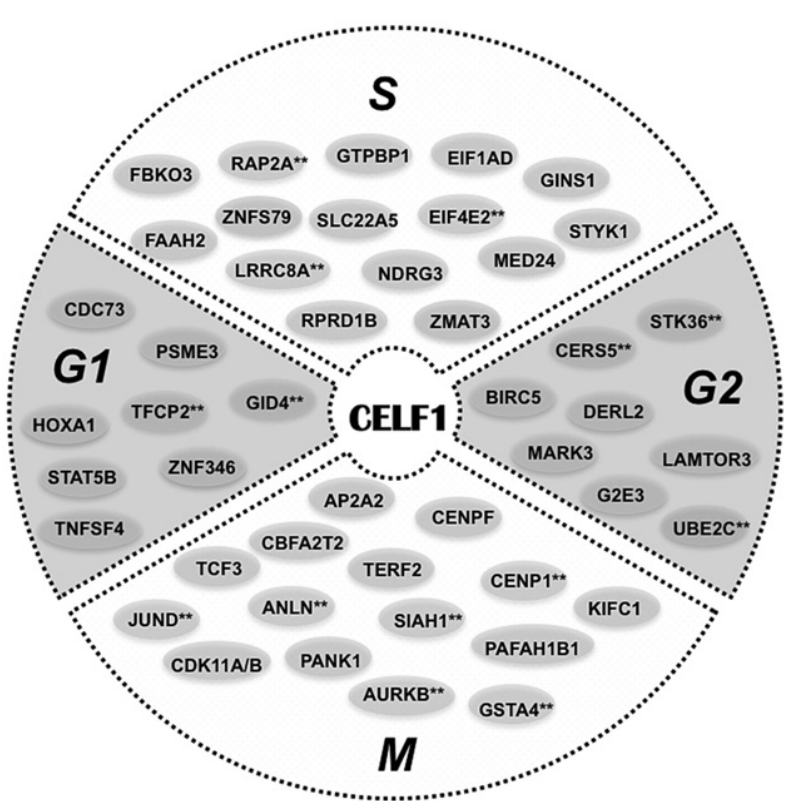

FIGURE 6. CELF1 targets in malignant T-cell lines encode cell cycle regulators. Ingenuity pathway analysis identified regulators of cell cycle as the top molecular network overrepresented among CELF1 targets in malignant $\mathrm{T}$ cells. This figure shows transcripts that were CELF1 targets in both $\mathrm{H} 9$ and Jurkat malignant $\mathrm{T}$ cells, but not normal $\mathrm{T}$ cells. The phases of the cell cycle $(\mathrm{G} 1, \mathrm{~S}, \mathrm{G} 2, \mathrm{M})$ indicate the cell cycle phase where the proteins encoded by these transcripts are thought to function (Ingenuity Knowledge Database). Transcripts indicated with double asterisks $\left(^{* *}\right)$ were also found to be CELF1 targets in the malignant HeLa cell line (Rattenbacher et al. 2010). This figure was built using Ingenuity Pathway Analysis, Canonical Pathways.

destabilization of transcripts that encode cell cycle checkpoint regulators or suppressors of proliferation.

CELF1 was phosphorylated in the H9 and Jurkat malignant T-cell lines (Figs. 2,3), and this phosphorylation correlated with decreased binding by CELF1 in malignant T-cell lines to its binding targets in normal $\mathrm{T}$ cells (Fig. 1). In fact, most CELF1 target transcripts expressed in normal $\mathrm{T}$ cells were not CELF1 targets in malignant T-cell lines, even though they were expressed in the malignant $\mathrm{T}$-cell lines. The lack of binding by CELF1 in malignant T-cell lines to transcripts that were CELF1 targets in normal $\mathrm{T}$ cells was not due to differences in the amount of CELF1 in the different cell types (see Fig. 2A), but appeared to be due to phosphorylation of CELF1 (Fig. 3), similar to what was observed in activated normal $\mathrm{T}$ cells (Beisang et al. 2012b). In normal $\mathrm{T}$ cells, CELF1 appears to be transiently phosphorylated following T-cell activation as part of the normal T-cell activation program, whereas in malignant $\mathrm{T}$ cells, CELF1 appears to be constitutively phosphorylated, with a more complex phosphorylation pattern. Also, we found CELF1 phosphorylation at serine 28 in malignant $\mathrm{T}$ cells but not in resting or activated normal $\mathrm{T}$ cells, indicating that the site of phosphorylation of CELF1 differs in normal and malignant T cells. PKC $\alpha / \beta I I-$ dependent phosphorylation of CELF1 at serine 28 is involved in murine heart development (Verma et al. 2013), but the role of phosphorylation of CELF1 at serine 28 in T cells has not been evaluated. Finding that CELF1 was phosphorylated at S28 in malignant $\mathrm{T}$ cells, but not in activated normal T cells suggests that different kinases that phosphorylate CELF1 at serine 28 , or other positions, are expressed or activated in malignant $\mathrm{T}$ cells. Although there is very little data regarding the role of PKC isozymes in CELF1 function, several studies have demonstrated the involvement of PKC isozymes in controlling cellular signaling and proliferation in malignant cells (for review, see Kang et al. 2012). PKC $\beta I I$, for example, plays a critical role in cancer cell proliferation, survival, and invasion. It is possible that cancer cells constitutively express kinases, such as PKC $\beta I I$, that phosphorylate CELF1 and alter its binding to target transcripts. Activation and proliferation in normal $\mathrm{T}$ cells is driven by $\mathrm{PKC} \theta$ and other kinases, including MAP kinases and PI3 kinase (for review, see Navarro and Cantrell 2014). Possibly, these kinases induced by T-cell activation lead to transient phosphorylation of CELF1, affecting the network of GRE-RNAs only for the amount of time needed for cellular activation and proliferation before $\mathrm{T}$ cells return to a quiescent state. At this point, further work is needed to define the sites of CELF1 phosphorylation in malignant $\mathrm{T}$ cells and during activation of normal $\mathrm{T}$ cells, but based on our findings, it appears that different kinases are involved, and CELF1 is hyperphosphorylated in malignant $\mathrm{T}$ cells relative to activated normal $\mathrm{T}$ cells.

Involvement of kinase signaling in regulating CELF1 binding to RNA is supported by our observation that immunopurified CELF1 from malignant T-cell lines or activated normal $\mathrm{T}$ cells exhibited decreased binding to a GRE-containing riboprobe, compared to immunopurified CELF1 from resting normal $\mathrm{T}$ cells (Fig. 4). Treating immunopurified CELF1 from malignant $\mathrm{T}$ cells or activated normal $\mathrm{T}$ cells with LPP led to increased GRE binding in vitro, suggesting that phosphorylation of CELF1 caused inhibition of binding (Fig. 4; Beisang et al. 2012b). Thus, for the large subset of GRE-containing transcripts that were CELF1 targets in normal $\mathrm{T}$ cells, lack of binding by CELF1 in malignant $\mathrm{T}$ cells was likely due to phosphorylation of CELF1. In contrast, we found that CELF1 acquired an ability to bind to a new subset

TABLE 3. Biological pathways, which were enriched among CELF1 target transcripts from malignant T cells

\begin{tabular}{ll}
\hline Diseases and disorders & Cancer \\
& Neurological disease \\
& Developmental \\
abnormalities \\
Molecular and cellular function & Cell cycle \\
& Cellular organization \\
& Cell death and survival \\
Physiological system development & Tumor morphology \\
and function & Tissue morphology \\
& Organ morphology \\
\hline
\end{tabular}


TABLE 4. CELF1 targets in resting T cells are stabilized and overexpressed in malignant T-cell lines and primary T-cell tumors

\begin{tabular}{|c|c|c|c|c|c|c|c|c|}
\hline RefSeq ID & Gene symbol & $\mathrm{FC} \mathrm{H9/T}$ & $\mathrm{FC} \mathrm{JK/T}$ & FC T-ALL/T & T cells HL & $\mathrm{H} 9 \mathrm{HL}^{\mathrm{a}}$ & $J \mathrm{KHL}^{\mathrm{a}}$ & T-ALL HL ${ }^{\mathrm{a}}$ \\
\hline NM_001066 & TNFRSF1B & 3.5 & 9.0 & 7.2 & $59(38,182)$ & $790(486,866)$ & $376(5,587)$ & $245(117,374)$ \\
\hline NM_006282 & STK4 & 1.8 & 1.9 & 2.4 & $77(57,199)$ & $684(194,813)$ & $308(61,491)$ & $351(101,498)$ \\
\hline NM_005542 & INSIG1 & 2.5 & 1.7 & 6.7 & $87(65,216)$ & $204(54,385)$ & $233(60,407)$ & $220(51,409)$ \\
\hline NM_002806 & PSMC6 & 2.3 & 2.4 & 1.9 & $48(9,314)$ & $297(72,470)$ & $367(74,545)$ & $254(80,411)$ \\
\hline NM_025164 & SIK3 & 1.5 & 1.8 & 6.2 & $99(28,129)$ & $790(486,896)$ & $376(56,587)$ & $270(13,519)$ \\
\hline NM_003340 & UBE2D3 & 1.4 & 2.0 & 3.8 & $53(19,229)$ & $423(119,568)$ & $461(96,623)$ & $113(27,349)$ \\
\hline NM_002577 & PAK2 & 1.5 & 1.8 & 6.4 & $58(44,143)$ & $333(68,517)$ & $308(61,706)$ & $409(36,709)$ \\
\hline NM_001252036 & RAB5B & 1.7 & 2.1 & 4.6 & $55(22,218)$ & $839(276,958)$ & $597(273,711)$ & $177(30,447)$ \\
\hline NM_005627 & TGFBR2 & 6.5 & 3.8 & 5.7 & $50(40,238)$ & $511(96,615)$ & $511(72,638)$ & $422(75,548)$ \\
\hline NM_006908 & RAC1 & 1.9 & 2.0 & 1.4 & $69(48,153)$ & $369(38,159)$ & $329(50,152)$ & $227(8,197)$ \\
\hline NM_005354 & JUND & 2.0 & 2.3 & 1.7 & $77(10,100)$ & $369(52,520)$ & $283(87,396)$ & $271(21,498)$ \\
\hline NM_005349 & RBPJ & 1.2 & 1.7 & 1.1 & $44(11,252)$ & $519(415,622)$ & $673(224,794)$ & $374(127,509)$ \\
\hline NM_005342 & HMGB3 & 1.7 & 2.2 & 4.6 & $98(20,274)$ & $310(146,435)$ & $433(204,552)$ & $249(41,472)$ \\
\hline NM_000462 & UBE3A & 1.4 & 2.0 & 1.3 & $63(59,166)$ & $214(17,610)$ & $367(261,474)$ & $364(99,471)$ \\
\hline NM_015633 & FGFR1OP2 & 2.4 & 6.3 & 7.6 & $51(11,238)$ & $505(346,612)$ & $518(173,645)$ & $177(160,512)$ \\
\hline
\end{tabular}

(RefSeq ID) Reference sequence annotated in NCBI; (JK) Jurkat; ( $\mathrm{HL}$ ) mean half-life; (Cl) confidence interval; (FC) fold change; (FCE) fold change in enrichment.

${ }^{a}$ The $P$-value for the difference in all transcript half-lives compared with normal T cells is $\leq 0.05$. Statistical significance was determined based on $n=3$ experiments for each malignant T-cell line, and $n=4$ donors for primary T cells or T-ALL tumors.

of target transcripts in malignant $T$ cells even though all cytoplasmic CELF1 was present in a phosphorylated form (Fig. 3). The mechanism by which CELF1 gained an ability to bind to these target transcripts is unknown. Perhaps, hyperphosphorylation of CELF1 led to changes in its affinity such that it lost the ability to bind to most GRE-containing target transcripts, but gained the ability to bind to a new set of GRE-containing transcripts. Sequence analysis of these new CELF1 target transcripts from malignant $\mathrm{T}$ cells revealed that they contain GRE sequences that are similar or identical to previously characterized GRE sequences, and therefore, the mechanistic details for preferential binding by CELF1 to these target transcripts are yet to be uncovered. Hyperphosphorylation of CELF1 in malignant $\mathrm{T}$ cells may lead to altered RNA-binding characteristics through changes in the CELF1 protein conformation, alterations in the functional activities of individual RNA-recognition motifs (RRMs), or the ability of CELF1 to associate with sequences that flank the GRE or other nearby sequences such that CELF1 gains new binding characteristics. Binding by CELF1 to RNA occurs via multiple RRMs (Edwards et al. 2011, 2013), and phosphorylation within one or more RRMs may change its binding characteristics. Although, all RRM motifs have been shown to bind to short GRE sequences with comparable affinity in vitro (Teplova et al. 2010), preferential binding to RNA by one, two or all three motifs could dictate differences in sequence-binding preferences. Alternatively, other binding proteins, microRNAs, or adjacent RNA cis-elements might interact with CELF1 and change its ability to bind to target mRNA. Further work is needed to understand why CELF1 binds to RNA differently in normal and malignant $\mathrm{T}$ cells.

We previously used microarrays to measure the decay rates of transcripts expressed in primary human T cells, H9 T cells, and Jurkat T cells (Vlasova et al. 2005), and now analyzed this data to determine whether differential binding by CELF1 to specific transcripts correlated with rates of mRNA degradation and transcript abundance. We found that many transcripts that were targets of CELF1 in normal $\mathrm{T}$ cells but not in the $\mathrm{H} 9$ or Jurkat malignant $\mathrm{T}$-cell lines were stabilized and up-regulated in the malignant $\mathrm{T}$ cells. This finding suggests that CELF1 bound to these transcripts in normal $\mathrm{T}$ cells and mediated their degradation, but since CELF1 did not bind to these transcripts in malignant cell lines, they were stabilized and their expression increased (Table 2). Thus, it appears that phosphorylation of CELF1 led to its functional inactivation, resulting in a failure of CELF1 to mediate the decay of a large set of GRE-containing transcripts in malignant T-cell lines. We have recently shown that numerous GREcontaining transcripts undergo shortening through alternative polyadenylation following T-cell activation, and similar transcript shortening has been shown to occur in malignancy (Mayr and Bartel 2009; Beisang et al. 2014). Thus, some of the transcripts that were targets of CELF1 in normal T cells but not in malignant $\mathrm{T}$ cells may have lost their GRE sequences due to alternative polyadenylation.

For a subset of the transcripts that were CELF1 targets in normal $\mathrm{T}$ cells but not malignant $\mathrm{T}$ cells that are involved in cell growth regulation, we measured mRNA degradation rates and abundance in primary T-ALL cells from four patients using QRT-PCR. We found that these transcripts were stabilized and up-regulated compared with normal $\mathrm{T}$ cells, similar to what was seen in malignant $\mathrm{T}$-cell lines (see Table 4). Although the small numbers of cells available did not allow us to perform RNA-IP or CELF1 phosphorylation experiments using T-ALL cells, the pattern of transcript stabilization and expression showed that numerous GRE- 
containing transcripts that were CELF1 targets in normal T cells were stabilized and up-regulated in primary tumor cells. Up-regulation of these transcripts in malignant $\mathrm{T}$ cells would be expected to facilitate cell growth and proliferation and would likely contribute to the malignant phenotype.

The dysregulation of CELF1 through inappropriate phosphorylation in malignant $\mathrm{T}$ cells appears to contribute to abnormal growth and promotes the malignant phenotype by blocking CELF1 binding and thereby stabilizing and increasing the expression of a large subset of GRE-containing transcripts. At the same time, CELF1 gains the ability to bind to and mediate the degradation of another subset of GRE-containing transcripts that encode checkpoint control proteins and suppressors of proliferation. Many of the CELF1 target transcripts identified in malignant $\mathrm{T}$-cell lines encode regulators of cell cycle transitions (Fig. 6), including important suppressors of cell proliferation such as JUND, CDKN1A, SIAH, AURKB, and others. Rapid CELF1-mediated degradation of these target transcripts in malignant $\mathrm{T}$ cells would favor growth and proliferation by shortening cell cycle checkpoint phases and expediting cell cycle phase transitions (VlasovaSt. Louis and Bohjanen 2011). Overrepresentation of CELF1 targets in malignant $\mathrm{T}$ cells among disease specific categories, such as cancer, reinforces the role for these transcripts in driving or promoting cancer pathogenesis. CELF1-mediated degradation of these transcripts in malignant $\mathrm{T}$ cells would decrease their expression and facilitate a proliferative state.

Overall, our results support a model whereby dysregulated kinases or kinase signaling pathways lead to phosphorylation of CELF1, which facilitates the development of the malignant phenotype by increasing the stability and expression of transcripts involved in cell proliferation. Acquisition of CELF1 binding to another set of transcripts in malignant cells leads to the degradation and down-regulation of transcripts encoding cell growth suppressors. Thus, CELF1 dysregulation in malignant $\mathrm{T}$ cells leads to the up-regulation of a subset of GRE-containing transcripts that promote cell growth, and down-regulation of another subset that suppresses cell growth, producing a net effect that would drive a malignant phenotype.

\section{MATERIALS AND METHODS}

\section{Cell culture, stimulation, and preparation of cytoplasmic extracts}

Culture of normal and malignant T-cell lines, stimulation of normal $\mathrm{T}$ cells with anti-CD3 and anti-CD28 antibodies, and preparation of cytoplasmic extracts were performed as described previously (Raghavan et al. 2002).

\section{RNA-IP followed by microarray analysis or RT-PCR}

RNA-IP, microarray analyses, and RT-PCR were performed as described previously (Vlasova et al. 2005, 2008; Rattenbacher et al.
2010). Three separate IP experiments were performed for microarray analyses for $\mathrm{H} 9$ and Jurkat cell lines, and IP experiments were performed from normal primary human $\mathrm{T}$ cells isolated from three different donors. The following antibodies were used for IP: antiCELF1/CUGBP1 (3B1), anti-HA (F7, Santa Cruz Biotechnology), or anti-PABP (10E10, ImmuQuest). Microarray data were analyzed as described previously (Beisang et al. 2012b) using Partek Genomics Suite (Partek). Briefly, the output signals were normalized using the Partek Robust Multi-Chip Average analysis adjusted for the GC content of probe sequence (GCRMA). The genes that were differentially expressed among different cell types were identified using the analysis of variance (ANOVA) as implemented in the Partek Gene Expression tool, with the $P$-value adjusted using step-up (Benjamini and Hochberg 1995) multiple test correction. mRNA transcripts were considered to be significantly differentially expressed if they obtained ANOVA $P$-value $\leq 0.005$ and FDR $\leq 0.15$. Transcripts were determined to be CELF1 targets if the difference between the $\log _{2}$ normalized signal from the microarrays hybridized with the cRNA from the anti-CELF1 RNA-IP and the anti-PABP RNA-IP was greater than the same value derived from the difference between the anti-HA RNA-IP and anti-PABP RNA-IP, with $P \leq$ 0.005 , as determined by Fisher exact test of two factor variables, in either cell IP types.

A pathway analysis of CELF1 target transcripts in malignant T-cell lines was performed with the Ingenuity Pathway Analysis software (IPA, Ingenuity Systems, http://www.ingenuity.com). For conventional RT-PCR reaction, mRNA in the immunoprecipitated complexes and $50 \mathrm{ng}$ of input fraction from $>3$ separate IP experiments were used in Superscript III reverse transcriptase (Invitrogen) reaction. cDNA were amplified using transcript-specific primers and PCR products were visualized on agarose gels. Forward and Reverse primers were designed to each mRNA of interest, using Primer-Blast software from National Center for Biotechnology Information, and posted in Supplemental Table 2 (http://www. ncbi.nlm.nih.gov/tools/primer-blast/).

\section{Sequence analyses of CELF1 target transcripts}

An algorithm, based on the Gibbs motif sampler, was used within the Partek Genomic Suite to detect de novo motifs in the 3' UTRs of CELF1 target transcripts in the $\mathrm{H} 9$ and Jurkat malignant T-cell lines (Neuwald et al. 1995; Favorov et al. 2005). Logo sequence was used to represent the output motifs.

\section{Two-dimensional gel electrophoresis and Western blotting}

Two-dimensional gel electrophoresis followed by Western blotting to characterize CELF1 phosphorylation was performed as described previously (Rattenbacher et al. 2010). Briefly, for two-dimensional gel electrophoresis, $80 \mu \mathrm{g}$ of cytoplasmic lysates were diluted 1:1 with Rehydration buffer from BioRad and dialyzed against 2D gel buffer (7 M urea, $2 \mathrm{M}$ thiourea, 2\% CHAPS, $10 \mathrm{mM}$ Tris) overnight at room temperature. The samples were then loaded onto $11-\mathrm{cm}$ pH3-10 IPG strips (BioRad). Samples were focused using a BioRad Protean IEF cell device. Subsequently, IPG strips were loaded onto Bis-Tris $4 \%-12 \%$ pre-cast gels and run at $175 \mathrm{~V}$ using MOPSSDS buffer. Gels were then blotted onto charged PVDF membranes. Western blots were performed probing with anti-CELF1 antibody 
and an anti-GAPDH antibody (Santa Cruz Biotechnology), or an anti-phospho-28S CELF1 antibody (Antagene).

\section{In vitro binding by immunopurified CELF1 to a GRE-riboprobe}

Binding by immunopurified CELF1 was performed as described in the Thermo Scientific IP protocol with slight modifications as described in Beisang et al. (2012b). In brief, CELF1 was immunoprecipitated out of $100 \mu \mathrm{g}$ of cytoplasmic lysate and samples were treated with $\lambda$-protein phosphatase (LPP) or were mock-treated. CELF1 was eluted from the beads by the addition of $0.5 \%$ SDS and heating at $65^{\circ} \mathrm{C}$ for $15 \mathrm{~min}$. The immunoprecipitated material was then incubated for $30 \mathrm{~min}$ with $50 \mathrm{fmol}$ of either the biotinylated GRE or mutant GRE-riboprobe, was treated with UV light ( $999 \mathrm{~J})$ and was eluted from the beads, separated on a $4 \%$ acrylamide gel. The biotinylated RNA probe signal was visualized with the Chemiluminescent Nucleic Acid Detection Module from Thermo Scientific, following the manufacturer's instructions. The blots were then stripped, and probed by Western blot with an antiCELF1 antibody. Images were then quantified with ImageJ to determine the RNA:CELF1 ratio.

\section{mRNA degradation assays}

Primary tumor cells isolated from peripheral blood of four T-ALL patients via leukapheresis were stored frozen in liquid nitrogen. Cells were thawed in warm RPMI-1640 (Invitrogen), by centrifugation on a $25 \%$ of human serum albumin cushion and were cultured for 2-3 d in RPMI-1640, supplemented with human serum albumin $(1.25 \mathrm{mg} / \mathrm{mL})$, recombinant human IL2 and IL7 (10 ng/mL for both; R\&D systems). To measure mRNA decay, Actinomycin D $(10 \mu \mathrm{g} / \mathrm{mL})$ was added to cultured cells and total cellular RNA was isolated at 0-, 1.5-, and 3-h time points. RT-QPCR using transcript-specific primers (see Supplemental Table 2) was used to quantitate the levels of individual mRNAs, which were normalized to the level of the expression of the HPRT transcript. For each transcript, normalized levels were used to calculate and compare transcript half-lives using GraphPad Prism 4 software, based on a linear first order exponential decay model $(P<0.05)$.

\section{SUPPLEMENTAL MATERIAL}

Supplemental material is available for this article.

\section{ACKNOWLEDGMENTS}

We thank the University of Minnesota Biomedical Genomics Center, Supercomputing Institute for analytical support, the Leukemia Hematologic Malignancy Tissue Bank for providing specimens, and students Mony Mak and Amanda Zeisel for technical assistance. Research was supported by institutional start-up funds to I.A.V-S.; National Institutes of Health grants AI096925 and AI072068 to P.R.B.; Howard Hughes Medical Institute and American Physiological Society (APS) scholarships for M.L.M., and a Clinical and Translational Science Institute (CTSI, University of Minnesota) scholarship for A.T.

Received January 19, 2015; accepted June 29, 2015.

\section{REFERENCES}

Arnal-Estapé A, Tarragona M, Morales M, Guiu M, Nadal C, Massagué J, Gomis RR. 2010. HER2 silences tumor suppression in breast cancer cells by switching expression of C/EBP $\beta$ isoforms. Cancer Res 70: 9927-9936.

Beisang D, Bohjanen PR. 2012. Perspectives on the ARE as it turns 25 years old. Wiley Interdiscip Rev RNA 3: 719-731.

Beisang D, Bohjanen P, Vlasova-St. Louis I. 2012a. CELF1, a multifunctional regulator of posttranscriptional networks. InTech 8: 181-206.

Beisang D, Rattenbacher B, Vlasova-St. Louis IA, Bohjanen PR. 2012b. Regulation of CUG-binding protein 1 (CUGBP1) binding to target transcripts upon T cell activation. J Biol Chem 287: 950-960.

Beisang D, Reilly C, Bohjanen PR. 2014. Alternative polyadenylation regulates CELF1/CUGBP1 target transcripts following T cell activation. Gene 550: 93-100.

Bemmo A, Dias C, Rose AA, Russo C, Siegel P, Majewski J. 2010. Exonlevel transcriptome profiling in murine breast cancer reveals splicing changes specific to tumors with different metastatic abilities. PLoS One 5: el1981.

Benjamini Y, Hochberg Y. 1995. Controlling the false discovery rate: a practical and powerful approach to multiple testing. J R Stat Soc B Met 57: 289-300.

Blackinton JG, Keene JD. 2014. Post-transcriptional RNA regulons affecting cell cycle and proliferation. Semin Cell Dev Biol 34: 44-54.

Choi HH, Choi HK, Jung SY, Hyle J, Kim BJ, Yoon K, Cho EJ, Youn HD, Lahti JM, Qin J, et al. 2014. CHK2 kinase promotes pre-mRNA splicing via phosphorylating CDK11 $1^{\mathrm{p} 110}$. Oncogene 33: 108-115.

Crawford DF, Piwnica-Worms H. 2001. The $\mathrm{G}_{2}$ DNA damage checkpoint delays expression of genes encoding mitotic regulators. J Biol Chem 276: 37166-37177.

Darvin P, Joung YH, Yang YM. 2013. JAK2-STAT5B pathway and osteoblast differentiation. JAKSTAT 2: e24931.

Edwards J, Malaurie E, Kondrashov A, Long J, de Moor CH, Searle MS, Emsley J. 2011. Sequence determinants for the tandem recognition of UGU and CUG rich RNA elements by the two N-terminal RRMs of CELF1. Nucleic Acids Res 39: 8638-8650.

Edwards JM, Long J, de Moor CH, Emsley J, Searle MS. 2013. Structural insights into the targeting of mRNA GU-rich elements by the three RRMs of CELF1. Nucleic Acids Res 41: 7153-7166.

Favorov AV, Gelfand MS, Gerasimova AV, Ravcheev DA, Mironov AA, Makeev VJ. 2005. A Gibbs sampler for identification of symmetrically structured, spaced DNA motifs with improved estimation of the signal length. Bioinformatics 21: 2240-2245.

Gareau C, Fournier MJ, Filion C, Coudert L, Martel D, Labelle Y, Mazroui R. 2011.p21 ${ }^{\text {WAF1/CIP1 }}$ upregulation through the stress granule-associated protein CUGBP1 confers resistance to bortezomibmediated apoptosis. PLoS One 6: e20254.

Goldenson B, Crispino JD. 2014. The aurora kinases in cell cycle and leukemia. Oncogene 34: 537-545.

Guerzoni C, Bardini M, Mariani SA, Ferrari-Amorotti G, Neviani P, Panno ML, Zhang Y, Martinez R, Perrotti D, Calabretta B. 2006. Inducible activation of $\mathrm{CEBPB}$, a gene negatively regulated by $\mathrm{BCR} / \mathrm{ABL}$, inhibits proliferation and promotes differentiation of BCR/ABL-expressing cells. Blood 107: 4080-4089.

Hahn MA, Dickson KA, Jackson S, Clarkson A, Gill AJ, Marsh DJ. 2012. The tumor suppressor CDC73 interacts with the ring finger proteins RNF20 and RNF40 and is required for the maintenance of histone 2B monoubiquitination. Hum Mol Genet 21: 559-568.

Halees AS, Hitti E, Al-Saif M, Mahmoud L, Vlasova-St. Louis IA, Beisang DJ, Bohjanen PR, Khabar K. 2011. Global assessment of GU-rich regulatory content and function in the human transcriptome. RNA Biol 8: 681-691.

Hernandez JM, Floyd DH, Weilbaecher KN, Green PL, Boris-Lawrie K. 2008. Multiple facets of junD gene expression are atypical among AP-1 family members. Oncogene 27: 4757-4767. 
Hu D, Valentine M, Kidd VJ, Lahti JM. 2007. CDK11 ${ }^{\mathrm{p} 58}$ is required for the maintenance of sister chromatid cohesion. J Cell Sci 120: 24242434.

Iakova P, Timchenko L, Timchenko NA. 2011. Intracellular signaling and hepatocellular carcinoma. Semin Cancer Biol 21: 28-34.

Kang JH, Toita R, Kim CW, Katayama Y. 2012. Protein kinase C (PKC) isozyme-specific substrates and their design. Biotechnol Adv 30: $1662-1672$.

Keene JD. 2007. RNA regulons: coordination of post-transcriptional events. Nat Rev Genet 8: 533-543.

Khabar KS. 2010. Post-transcriptional control during chronic inflammation and cancer: a focus on AU-rich elements. Cell Mol Life Sci 67: 2937-2955.

Kramer OH, Stauber RH, Bug G, Hartkamp J, Knauer SK. 2013. SIAH proteins: critical roles in leukemogenesis. Leukemia 27: 792-802.

Lee JE, Lee JY, Wilusz J, Tian B, Wilusz CJ. 2010. Systematic analysis of cis-elements in unstable mRNAs demonstrates that CUGBP1 is a key regulator of mRNA decay in muscle cells. PLoS One 5: e11201.

Li Y, Du X, Li F, Deng Y, Yang Z, Wang Y, Pen Z, Wang Z, Yuan W, Zhu C, et al. 2006. A novel zinc-finger protein ZNF436 suppresses transcriptional activities of AP-1 and SRE. Mol Biol Rep 33: 287-294.

Lokody I. 2014. Signalling: FOXM1 and CENPF: co-pilots driving prostate cancer. Nat Rev Cancer 14: 450-451.

Mayr C, Bartel DP. 2009. Widespread shortening of 3'UTRs by alternative cleavage and polyadenylation activates oncogenes in cancer cells. Cell 138: 673-684.

McDaniel LD, Schultz RA, Friedberg EC. 2006. TERF2-XPF: caught in the middle; beginnings from the end. DNA Repair (Amst) 5: 868872.

Mukherjee N, Lager PJ, Friedersdorf MB, Thompson MA, Keene JD. 2009. Coordinated posttranscriptional mRNA population dynamics during T-cell activation. Mol Syst Biol 5: 288.

Navarro MN, Cantrell DA. 2014. Serine-threonine kinases in TCR signaling. Nat Immunol 15: 808-814.

Neuwald AF, Liu JS, Lawrence CE. 1995. Gibbs motif sampling: detection of bacterial outer membrane protein repeats. Protein Sci 4: $1618-1632$.

Ogilvie RL, Abelson M, Hau HH, Vlasova I, Blackshear PJ, Bohjanen PR. 2005. Tristetraprolin down-regulates IL-2 gene expression through AU-rich element-mediated mRNA decay. J Immunol 174: 953-961.

Ogilvie RL, Sternjohn JR, Rattenbacher B, Vlasova IA, Williams DA, Hau HH, Blackshear PJ, Bohjanen PR. 2009. Tristetraprolin mediates interferon- $\gamma$ mRNA decay. J Biol Chem 284: 11216-11223.

Parikh N, Hilsenbeck S, Creighton CJ, Dayaram T, Shuck R, Shinbrot E, Xi L, Gibbs RA, Wheeler DA, Donehower LA. 2014. Effects of TP53 mutational status on gene expression patterns across 10 human cancer types. J Pathol 232: 522-533.

Raghavan A, Bohjanen PR. 2004. Microarray-based analyses of mRNA decay in the regulation of mammalian gene expression. Brief Funct Genomic Proteomic 3: 112-124.

Raghavan A, Ogilvie RL, Reilly C, Abelson ML, Raghavan S, Vasdewani J, Krathwohl M, Bohjanen PR. 2002. Genome-wide analysis of mRNA decay in resting and activated primary human $\mathrm{T}$ lymphocytes. Nucleic Acids Res 30: 5529-5538.

Rattenbacher B, Beisang D, Wiesner DL, Jeschke JC, von Hohenberg M, St. Louis-Vlasova IA, Bohjanen PR. 2010. Analysis of CUGBP1 targets identifies GU-repeat sequences that mediate rapid mRNA decay. Mol Cell Biol 30: 3970-3980.

Roy D, Arason GA, Chowdhury B, Mitra A, Calaf GM. 2010. Profiling of cell cycle genes of breast cells exposed to etodolac. Oncol Rep 23: $1383-1391$.
Starr TK, Allaei R, Silverstein KA, Staggs RA, Sarver AL, Bergemann TL, Gupta M, O'Sullivan MG, Matise I, Dupuy AJ, et al. 2009. A transposon-based genetic screen in mice identifies genes altered in colorectal cancer. Science 323: 1747-1750.

Talwar S, Balasubramanian S, Sundaramurthy S, House R, Wilusz CJ, Kuppuswamy D, D'Silva N, Gillespie MB, Hill EG, Palanisamy V. 2013. Overexpression of RNA-binding protein CELF1 prevents apoptosis and destabilizes pro-apoptotic mRNAs in oral cancer cells. RNA Biol 10: 277-286.

Teplova M, Song J, Gaw HY, Teplov A, Patel DJ. 2010. Structural insights into RNA recognition by the alternate-splicing regulator CUG-binding protein 1. Structure 18: 1364-1377.

Ting SB, Deneault E, Hope K, Cellot S, Chagraoui J, Mayotte N, Dorn JF, Laverdure JP, Harvey M, Hawkins ED, et al. 2012. Asymmetric segregation and self-renewal of hematopoietic stem and progenitor cells with endocytic Ap2a2. Blood 119: 2510-2522.

Turner M, Hodson D. 2012. Regulation of lymphocyte development and function by RNA-binding proteins. Curr Opin Immunol 24: $160-165$.

Valdivia MM, Hamdouch K, Ortiz M, Astola A. 2009. CENPA a genomic marker for centromere activity and human diseases. Curr Genomics 10: 326-335.

Verma SK, Deshmukh V, Liu P, Nutter CA, Espejo R, Hung ML, Wang GS, Yeo GW, Kuyumcu-Martinez MN. 2013. Reactivation of fetal splicing programs in diabetic hearts is mediated by protein kinase C signaling. J Biol Chem 288: 35372-35386.

Vlasova IA, Bohjanen PR. 2008. Posttranscriptional regulation of gene networks by GU-rich elements and CELF proteins. RNA Biol 5: 201-207.

Vlasova IA, McNabb J, Raghavan A, Reilly C, Williams DA, Bohjanen KA, Bohjanen PR. 2005. Coordinate stabilization of growth-regulatory transcripts in T cell malignancies. Genomics 86: 159-171.

Vlasova IA, Tahoe NM, Fan D, Larsson O, Rattenbacher B, Sternjohn JR, Vasdewani J, Karypis G, Reilly CS, Bitterman PB, et al. 2008. Conserved GU-rich elements mediate mRNA decay by binding to CUG-binding protein 1. Mol Cell 29: 263-270.

Vlasova-St. Louis I, Bohjanen PR. 2011. Coordinate regulation of mRNA decay networks by GU-rich elements and CELF1. Curr Opin Genet Dev 21: 444-451.

Vlasova-St. Louis I, Bohjanen PR. 2014. Post-transcriptional regulation of cytokine signaling by AU-rich and GU-rich elements. J Interferon Cytokine Res 34: 233-241.

Vlasova-St. Louis I, Dickson AM, Bohjanen PR, Wilusz CJ. 2013. CELFish ways to modulate mRNA decay. Biochim Biophys Acta 1829: 695-707.

Wang GL, Salisbury E, Shi X, Timchenko L, Medrano EE, Timchenko NA. 2008. HDAC1 promotes liver proliferation in young mice via interactions with C/EBP $\beta$. J Biol Chem 283: 2617926187.

Wu J, Li C, Zhao S, Mao B. 2010. Differential expression of the Brunol/ CELF family genes during Xenopus laevis early development. Int $J$ Dev Biol 54: 209-214.

Yang X, An L, Li X. 2013. NDRG3 and NDRG4, two novel tumor-related genes. Biomed Pharmacother 67: 681-684.

Zimdahl B, Ito T, Blevins A, Bajaj J, Konuma T, Weeks J, Koechlein CS, Kwon HY, Arami O, Rizzieri D, et al. 2014. Lis1 regulates asymmetric division in hematopoietic stem cells and in leukemia. Nat Genet 46: $245-252$. 

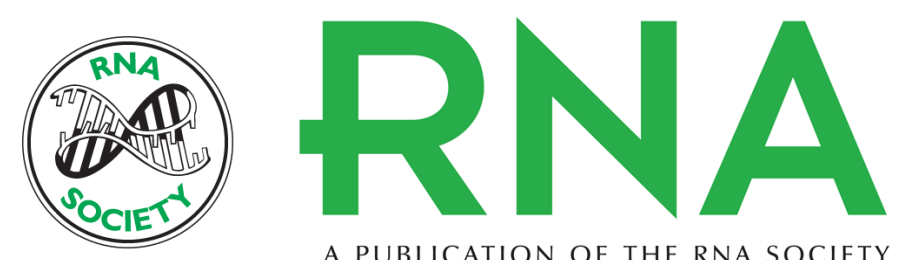

A PUBLICATION OF THE RNA SOCIETY

\section{Altered CELF1 binding to target transcripts in malignant T cells}

Paul R. Bohjanen, Mai Lee Moua, Liang Guo, et al.

RNA 2015 21: 1757-1769 originally published online August 6, 2015

Access the most recent version at doi:10.1261/rna.049940.115

Supplemental Material

References

Creative Commons License

Email Alerting Service
http://rnajournal.cshlp.org/content/suppl/2015/07/29/rna.049940.115.DC1

This article cites 58 articles, 12 of which can be accessed free at: http://rnajournal.cshlp.org/content/21/10/1757.full.html\#ref-list-1

This article is distributed exclusively by the RNA Society for the first 12 months after the full-issue publication date (see http://rnajournal.cshlp.org/site/misc/terms.xhtml). After 12 months, it is available under a Creative Commons License (Attribution-NonCommercial 4.0 International), as described at http://creativecommons.org/licenses/by-nc/4.0/.

Receive free email alerts when new articles cite this article - sign up in the box at the top right corner of the article or click here.

To subscribe to $R N A$ go to:

http://rnajournal.cshlp.org/subscriptions 